\title{
Structural and ultrastructural characterization of the floral lip in Gongora bufonia (Orchidaceae): understanding the slip-and-fall pollination mechanism
}

\author{
Sérgio Akira Adachi, Silvia Rodrigues Machado, and Elza Guimarães
}

\begin{abstract}
In this study, we investigated the pollination ecology and floral lip morphology of Gongora bufonia Lindl., an epiphytic orchid from tropical forest, to better understand the peculiarities of its unusual pollination mechanism. Field observations on pollination were performed and floral lip samples were prepared for anatomical, histochemical, and ultrastructural analyses. Male Eufriesea violacea (Blanchard) bees use the second and third pairs of legs to hold on the epichile and collect the fragrance in the hypochile region. During this process, the bee slips and falls on the column and receives the pollinarium, which is attached to the rear edge of the bee's scutellum. A subsequent visit (usually to another flower) and fall through the flower may result in insertion of a pollinium into the stigmatic slit at the apex of the column. The fragrance production occurs in the hypochile region, specifically in the papillose epidermal cells and in the subepidermal parenchyma layers. The wax production occurs in the epichile region, exclusively in the epidermal cells. The cells of both regions, hypochile and epichile, have ultrastructural features of lipophilic secretion. The slippery quality of the epichile epidermis is due to wax deposits; this is probably essential to the pollination mechanism of $G$. bufonia.
\end{abstract}

Key words: fragrance, Gongora, Orchidaceae, pollination, ultrastructure, wax.

Résumé : Dans cette étude, les auteurs ont examiné l'écologie de la pollinisation et la morphologie du labelle de Gongora bufonia Lindl., une orchidée épiphyte de la forêt tropicale, afin de mieux comprendre les particularités de son mécanisme inhabituel de pollinisation. Les observations de la pollinisation ont été réalisées sur le terrain et des échantillons de labelle ont été préparés aux fins d'analyses anatomiques, histochimiques et ultra-structurales. Les abeilles mâles Eufriesea violacea (Blanchard) utilisent les deuxième et troisième paires de pattes pour se retenir à l'épichile et recueillir la fragrance de la région de l'hypochile. Au cours de ce processus, l'abeille glisse et tombe sur la colonne pour recevoir la pollinie, qui est attachée à l'extrémité postérieure du scutellum de l'abeille. Une visite subséquente (habituellement sur une autre fleur) et la chute dans la fleur peut résulter en l'insertion d'une pollinie dans la fente stigmatique à l'apex de la colonne. La production de fragrance se déroule dans la région de l'hypochile, spécifiquement dans les cellules épidermiques papilleuses et dans les couches parenchymateuses sous-épidermiques. La production de cire se déroule dans la région de l'épichile, exclusivement dans les cellules épidermiques. Les cellules des deux régions, l'hypochile et l'épichile, possèdent des caractéristiques ultra-structurales d'une sécrétion lipophile. Le caractère glissant de l'épiderme de l'épichile est dû au dépôt de cire, ce qui est probablement essentiel au mécanisme de pollinisation de G. bufonia. [Traduit par la Rédaction]

Mots-clés : fragrance, Gongora, Orchidaceae, pollinisation, ultrastructure, cire.

\section{Introduction}

Orchidaceae is an important Neotropical family, and $10 \%$ of all species offer fragrance as the only floral resource (van der Pijl and Dodson 1966; Willmer 2011). Interaction with males from the tribe Euglossini (Apidae), which collect fragrance as a resource, has been reported in almost 650 neotropical orchids (Dressler 1982; Williams 1982). Scent gathering occurs through secretions derived from fatty acids that are produced by bees' cephalic labial glands. These lipids are mostly unbranched chains of hydrocarbons, alcohols, esters, acetates, and diacetates, which are scattered on surfaces that produce fragrance,

Received 12 June 2015. Accepted 18 August 2015.

S.A. Adachi. Postgraduate Program in Biological Sciences (Botany), São Paulo State University - UNESP, Institute of Biosciences, 18618-970 Botucatu, São Paulo State, Brazil.

S.R. Machado. São Paulo State University - UNESP, Institute of Biosciences, Department of Botany and Centro de Microscopia Eletrônica, 18618-970 Botucatu, São Paulo State, Brazil.

E. Guimarães. São Paulo State University - UNESP, Institute of Biosciences, Department of Botany, 18618-970 Botucatu, São Paulo State, Brazil.

Corresponding author: Elza Guimarães (e-mail: eguimaraes@ibb.unesp.br). 
thus aiding the dissolution and retention of volatiles (Whitten et al. 1989, 1993). Male bees scrape up the secretion from the flower lip using the brush-like portion of the front tarsi, and after collection, the mixture of labial secretions and collected fragrances are transferred to the surface of the swollen hind tibial organ (Cruz-Landim et al. 1965; Dressler 1982). The mixture is drawn into the interior of the tibial organ by capillary action (Whitten et al. 1989; Eltz et al. 1999). The role of this secretion in Euglossini biology has been investigated, and some experiments have shown that male bees actively ventilate the blend of fragrances whilst in circling flight in the forest understory, but it is still not clear whether this acts as a signal to female or male bees (Bembé 2004; Eltz et al. 2005; Zimmermann et al. 2006).

In angiosperms, the site of fragrance synthesis and release corresponds to specialized glandular tissue called the osmophores (Vogel 1990). In Orchidaceae, the osmophores are usually present on the adaxial surface of sepals or petals, or at variable portions of the floral lip (Dressler 1993), and their structure can vary on interspecific and intergeneric levels (Williams and Whitten 1983). This secretory tissue consists of epidermis that may vary from smooth to wrinkled or papillose, subtended by several layers of secretory parenchyma cells followed by common parenchyma cells (Stern et al. 1987; Vogel 1990; Curry et al. 1991; Ascensão et al. 2005; Pansarin et al. 2009). The morphology of osmophores in the Stanhopeinae tribe and in related taxa that are pollinated by Euglossini bees, varies from several layers of secretory cells as in the genus Clowesia, to trichomes in Polycycnis, and papillae in some species of Stanhopea and Gongora (Stern et al. 1987).

Gongora Ruiz \& Pav. is a genus of Orchidaceae that belongs to the Stanhopeinae subtribe and contains around 50 neotropical species. The flowers produce terpenes and aromatic compounds that are involved in pollinator attraction (Williams 1982; Williams and Whitten 1983). In this genus, male Euglossini bees collect the fragrance produced in the floral lip and, when leaving the flower, they fall down on the column and receive the pollinaria on their scutellum (Allen 1954; Dressler 1968). This interaction was described by Dressler (1982) as an unusual mechanism that depends on the bee slipping and falling through a flower. In fact, this peculiar type of pollination was described for Gongora maculata (Allen 1954) and for other species belonging to the Gongora quinquenervis complex (Dressler 1968; Martini et al. 2003). Considering that other members of Stanhopeinae also depend upon the bee slipping from a waxy surface and falling through the flower (Pansarin and Amaral 2009) or falling into a bucket, a detailed description of the floral structure associated with pollination is important to better understand this pollination mechanism.

The aim of this study was to investigate the pollination ecology and floral morphology of Gongora bufonia Lindl. to determine the features that account for this peculiar pollination mechanism.

\section{Material and methods}

Plant material

Gongora bufonia is an epiphytic species with light green, ovoid, and deeply grooved pseudobulbs, and pale green, broad, petiolated, elliptic-lanceolate leaves, with prominent longitudinal ribs. The non-resupinate flowers are arranged on a pendent raceme and are rosy with red stains; sepals are membranous; the lip is divided into three distinct regions called hypochile (base), mesochile (middle portion), and epichile (apex) (Fig. 1). Other morphological features are presented in the descriptions of Hoehne (1942) and Romanini and Barros (2007). This species occurs in southern and southeastern tropical rain forests in Brazil, between the Rio de Janeiro and Santa Catarina states (Hoehne 1942).

\section{Study area}

For pollination biology studies, we observed five G. bufonia individuals in a fragment of seasonal semideciduous tropical forest located in the Botanical Garden from Universidade Estadual Paulista (UNESP) Bioscience Institute (JB/IBB) - Botucatu (São Paulo, Brazil, 22 $53^{\prime} 09^{\prime \prime}$ S, $48^{\circ} 29^{\prime} 54^{\prime \prime} \mathrm{W}, 850 \mathrm{~m}$ a.s.1.). The plants cultivated in a greenhouse (collection numbers BOT 167, 211, 212, 217, and 253) were exposed to the pollinators during the flowering period.

\section{Floral biology}

We performed field observations on floral events and floral visitors in October and November from 2008 to 2010, and in 2013. The floral visitors were recorded throughout the daylight period, from 0800 to 1800 from the beginning of anthesis until flower senescence, totaling around $60 \mathrm{~h}$ of focal observation according to Dafni et al. (2005), and an additional $15 \mathrm{~h}$ of photo and video recording. We analyzed the floral visitor's behaviour through direct observation, photographs, and video recordings. Specimens of floral visitors were collected and sent to specialists for taxonomic identification.

Scent was evaluated by the organoleptic test and flowers were immersed in $0.1 \%(w / v)$ aqueous neutral red for 2-24 h (Vogel 1963) to locate the site of scent emission.

\section{Structural and ultrastructural studies}

For scanning electron microscopy (SEM) analysis, floral lip samples from functional flowers (first day of anthesis) were fixed in $2.5 \%$ glutaraldehyde $\left(0.1 \mathrm{~mol} \cdot \mathrm{L}^{-1}\right.$ phosphate buffer, $\mathrm{pH}$ 7.2), dehydrated in a graded ethanol series and critical point dried. The bee samples were dried for $24 \mathrm{~h}$ in a stove with air circulation before being mounted. Samples were mounted on aluminum stubs, coated with gold $(10 \mathrm{~nm})$, and examined under a Quanta 200 scanning electron microscope (Fei Company, FEI, Gräfelfing, Germany) at $20 \mathrm{kV}$. 
Fig. 1. Gongora bufonia flowers and pollination mechanism. (a) Gongora bufonia flower with dorsal sepal (DS), lateral sepals (LS), petals (Pt), column (Co), and floral lip divided into hypochile (Hc), mesochile (Mc), and epichile (Ec). (b) Eufriesea violacea with pollinarium attached to the scutellum (arrowhead) just after landing on the floral lip. (c) Most common position of fragrance gathering by E. violacea. (d) Bee falling towards the column. Scale bars $=1 \mathrm{~cm}$. (This figure is available in colour online.)
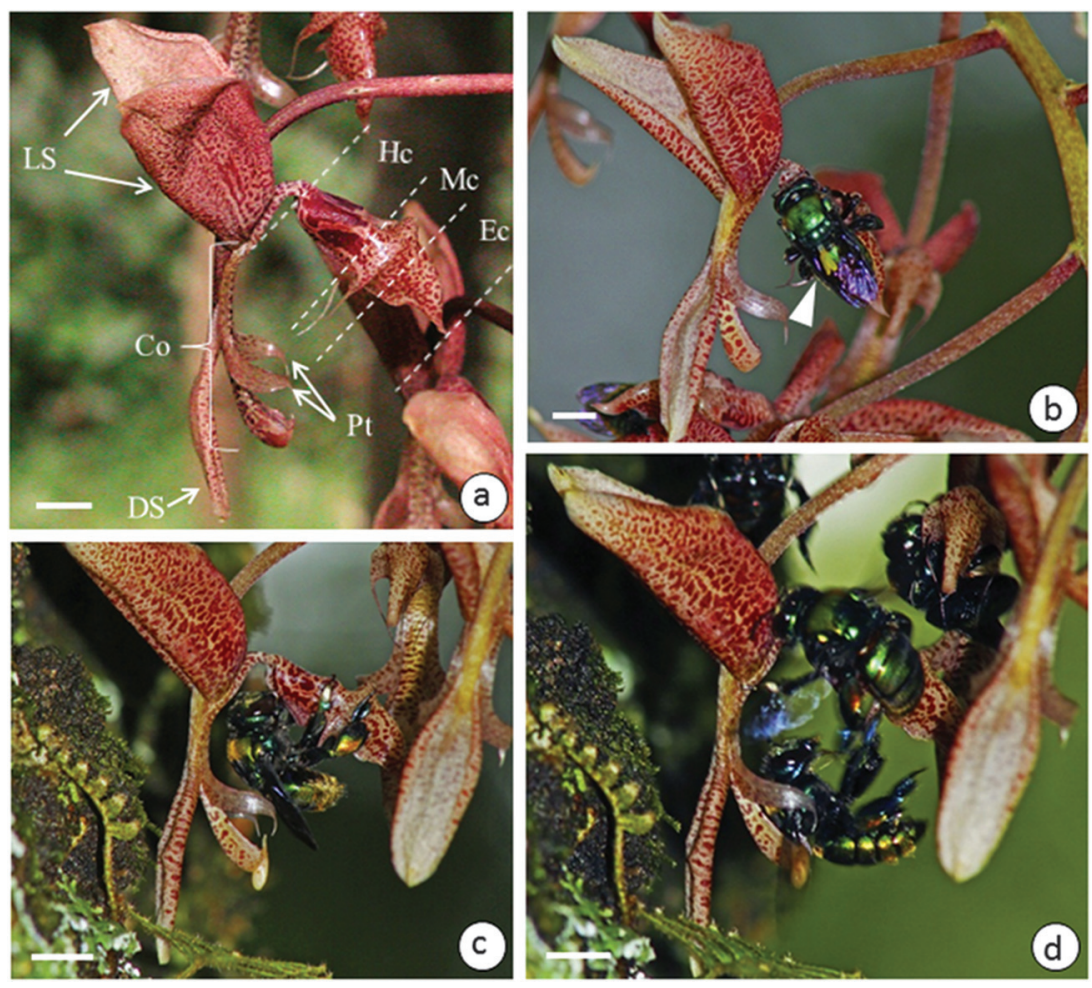

For anatomical studies by light microscopy (LM), preanthesis buds (one day before anthesis) and first-day flowers were fixed in FAA 50 (formaldehyde, acetic acid, and 50\% ethanol, 1:1:18 $v / v / v$ ) (Johansen 1940) for $24 \mathrm{~h}$, dehydrated in a graded ethanol series, and embedded in Leica Historesin (Leica Microsystems Inc., Heidelberger, Germany). Transverse sections of the hypochile and epichile regions were cut to $6 \mu \mathrm{m}$ thickness using a rotary microtome and stained with $0.05 \%$ toluidine blue (pH 4.3) (O’Brien et al. 1964). To determine the chemical composition of the cellular inclusion, samples were subjected to histochemical tests, with standard control procedures, as shown in Table 1.

To characterize the cellular aspects of fragrance and wax producing regions, we selected the lip portions directly linked to the pollination mechanism, based on the observation of bees' behaviour. So, samples from the ventral region of the hypochile and from the entire epichile of first-day flowers were prepared for transmission electron microscopy (TEM) analysis. Pieces $2 \mathrm{~mm}^{2}$ in size were dissected from the floral lip, fixed in glutaraldehyde (2.5\% with $0.1 \mathrm{~mol} \cdot \mathrm{L}^{-1}$ phosphate buffer, $\mathrm{pH} 7.2$ ), and left overnight at $4{ }^{\circ} \mathrm{C}$. They were then post-fixed with $1 \%$ osmium tetroxide $\left(\mathrm{OsO}_{4}\right)$ solution in the same buffer for $2 \mathrm{~h}$ at room temperature, dehydrated in a graded acetone solution series, and embedded in Araldite resin. Ultrathin sections were stained with uranyl acetate and lead citrate (Reynolds 1963), and examined with a Tecnai Spirit TEM (FEI) at $60 \mathrm{kV}$.

\section{Results}

Pollination ecology

The inflorescence of G. bufonia showed synchronous blooming, with around nine flowers opening at 0800 during the first day. The anthesis lasted for 2 days and even the visited flowers retained their colour during this time. Abscission of the non-fertilized flowers occurred between the third and fourth day. A slight scent could be detected at the beginning of anthesis, and at around 1000, it became stronger. The floral lip has three distinct regions: hypochile, mesochile, and epichile (Fig. 1a). The bee visits occurred from 1030 until 1500. Each individual bee spent 4-5 min in one inflorescence visiting several flowers in a sequence, except for one male that visited the same inflorescence for $15 \mathrm{~min}$ and spent 6 min at a single flower. We only observed males of Eufriesea violacea (Blanchard) visiting the flowers of G. bufonia and some of them had the pollinarium attached to the scutellum (Fig. 1b).

During the visits, the males hovered in front of the inflorescence for several minutes before alighting on the floral lip side (Fig. 1b). At this moment, they held onto the epichile with their hind legs, and onto the mesochile with their middle legs. Immediately after landing, these 
Table 1. Histochemical analysis of the Gongora bufonia floral lip.

\begin{tabular}{|c|c|c|c|c|}
\hline Reagent & Target compounds & Reference & Reactivity & Site \\
\hline Sudan IV & Total lipids & Johansen (1940) & + & $\begin{array}{l}\text { Cuticle, epidermal, and } \\
\text { subepidermal cells }\end{array}$ \\
\hline Nadi (N-dimethyl-p-phenylenediamine) & Terpenes & David and Carde (1964) & + & Cuticle \\
\hline Lugol & Starch grains & Johansen (1940) & + & $\begin{array}{l}\text { Epidermal and parenchyma } \\
\text { cells }\end{array}$ \\
\hline Dragendorff & Alkaloids & Svendsen and Verpoorte (1983) & - & \\
\hline Mercury bromophenol blue & Proteins & Mazia et al. (1953) & - & \\
\hline Ferric trichloride & Phenolic compounds & Johansen (1940) & - & \\
\hline
\end{tabular}

Note: -, negative; +, positive.

bees started brushing the floral lip in its lateral portion and moving towards the ventral portion of the hypochile region, revealing their ventral region facing the floral lip and their dorsal region facing the column (Fig. 1c). The bees usually scraped up the hypochile for 5-40 s using their front tarsi.

During this process, the bee slipped from the floral lip several times and fell directly on the column. Next, the bee slid down the column passing by the stigma and anther region because of the constraint imposed by the two petals adnate to both sides of the column. These petals kept the bees imprisoned for a few seconds in the apical portion of the column (Fig. 1d), thus preventing the bee from immediately taking off. The adnate petals also have a mechanical function that helps to spread the bee's wings so that the viscidium can attach directly to the scutellum, carrying the pollinia. After a brief period of apparent disorientation, probably due to the fall, the bee typically took off and went to visit another flower, which was usually in the same inflorescence.

Sometimes when the bees left the flowers, they hovered in front of the inflorescence for 2-5 s. During this period, the bees brushed their front legs on their middle legs, and then their middle legs on their swollen hind tibiae. The front legs of E. violacea males, which were used to scrape the hypochile surface, were densely covered with bristles (Fig. 2a). The fragrance-lipid mixture was stored in the dilated portion of the hind tibia (Fig. 2b). Inside the dilated hind tibia, there was a net of villosities and bristles that resembled a spongy sac (Fig. 2c).

Based on the behaviour of the bees and on direct olfactory tests, the scent production regions appear to be located on the hypochile and lateral sepals. However, based on direct olfactory tests, the scent was stronger on the hypochile. A positive reaction with neutral red could not be identified on G. bufonia.

Floral lip micromorphology, anatomy, and ultrastructure

Micromorphological (SEM) and anatomical (LM) analysis of the floral lip showed a clear distinction between the hypochile, where the osmophores are located, and the epichile, which is involved in wax secretion.
Fig. 2. Scanning electron micrographs of Eufriesea violacea legs. (a) Eufriesea violacea front leg with bristles (arrowhead). (b) Eufriesea violacea hind leg with swollen tibia and site of fragrance storage (arrowhead). (c) Internal part of the hind tibia with a complex net of villosities and bristles. Scale bars $=1 \mathrm{~mm}$ (Figs. $2 a, 2 b$ ); $500 \mu \mathrm{m}$ (Fig. $2 c$ ).
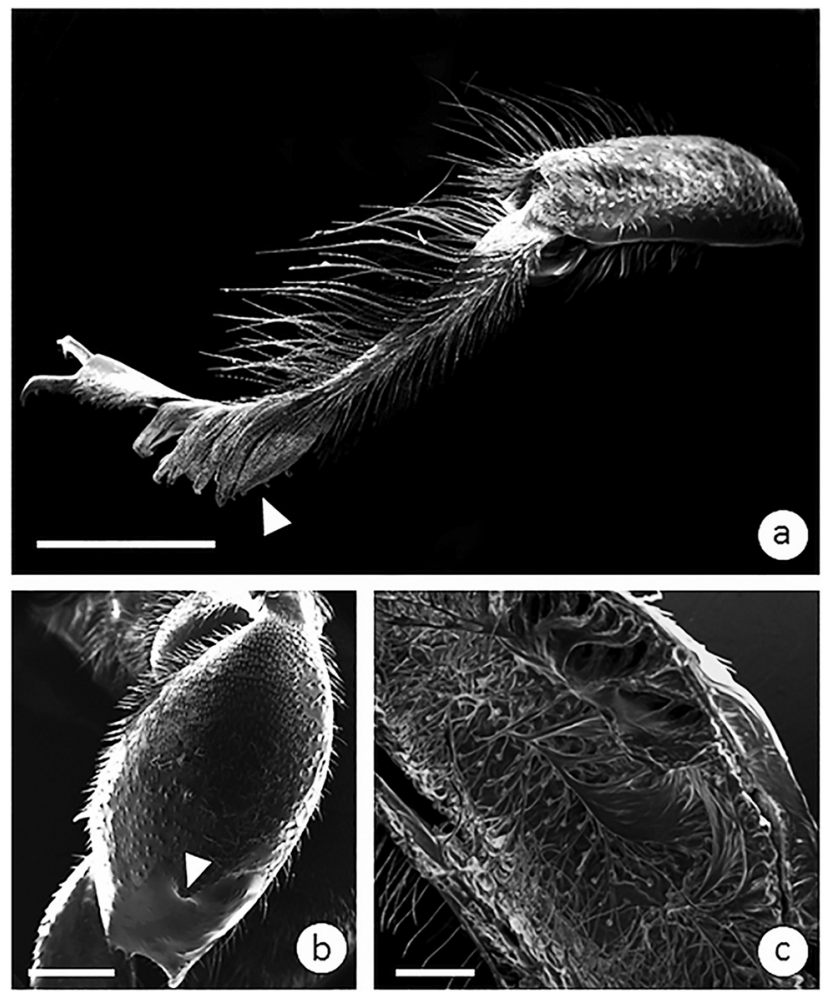

By SEM, conical papillose cells were observed on the hypochile's surface (Fig. 3a), showing a decrease in height from the dorsal to the ventral surface (Figs. $3 b, 3 c$ ). The ventral surface was characterized by short papillose cells comprising multiple parallel ridges, which increased significantly the hypochile surface area (Fig. 3d). This region was covered with a smooth cuticle and some accumulations of amorphous material were registered in the depressions between the ridges (Fig. $3 d$ ). The epichile had polygonal epidermal cells (Fig. $3 e$ ) that were covered with grains of epicuticular wax (Figs. 3e, 3f). 
Fig. 3. Scanning electron micrographs of G. bufonia floral lip. (a-d) Hypochile. (e-f) Epichile. (a) General aspect of the hypochile region. (b) Long conical papillose cells on the dorsal portion. (c) Conical papillose cells on the lateral portion of the lip. (d) Epidermis of the ventral portion with small papillae and ridges; accumulations of amorphous material between ridges (inset arrowheads) (e) Epichile with wax deposits. (f) Detail of the epichile with rectangular cells covered by wax grains. Scale bars = $1 \mathrm{~mm}$ (Fig. 3a); $100 \mu \mathrm{m}$ (Figs. 3c-3e); $50 \mu \mathrm{m}$ (Fig. 3b); $25 \mu \mathrm{m}$ (Figs. $3 d$ inset, 3f).
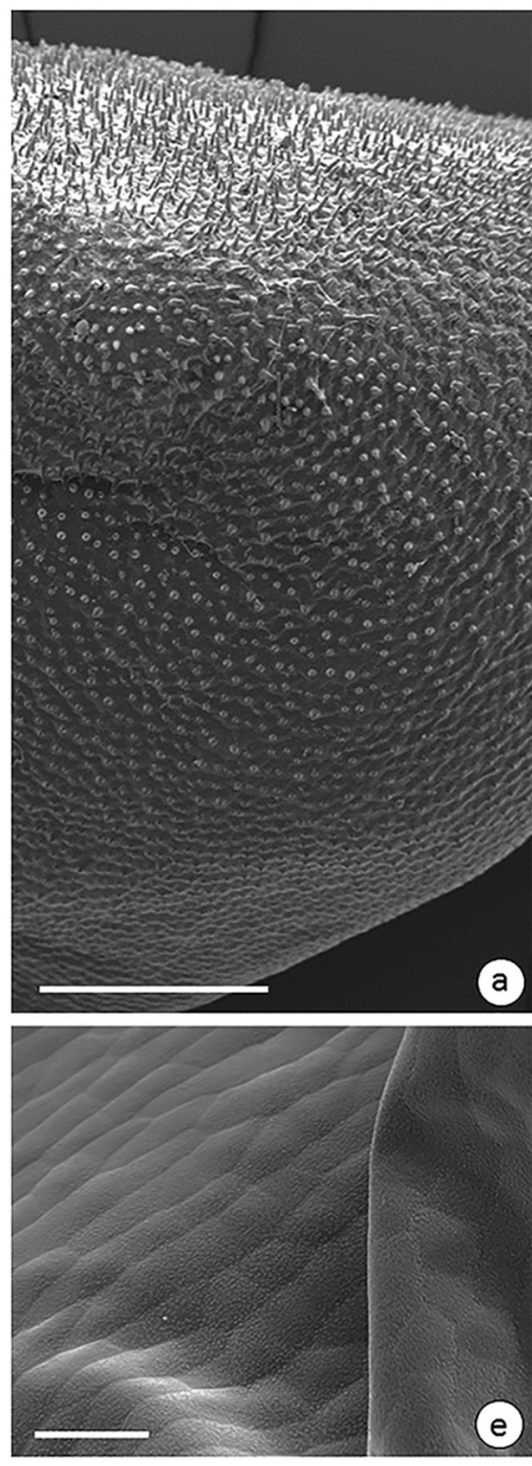

By LM, a uniseriate epidermis with papillose cells and a vascularized parenchyma with two or three secretory subepidermal layers (Figs. $4 a, 4 b$ ) were observed in the hypochile region. Accumulations of lipophilic material, detected with Sudan IV (total lipids) (Fig. 4c) and Nadi reagent (terpene compounds) (Fig. 4d), were observed on the outer periclinal walls and over the cuticle of the hypochile's ventral surface in first-day flowers. The placement of these accumulations, mainly between ridges, corresponds to the amorphous material accumulation site observed by SEM. Lipid droplets (Fig. 4e) and starch grains (Fig. 4f) were observed in the subepidermal parenchyma cells in pre-anthesis buds. First-day flowers had a hypochile epidermis and contiguous parenchyma cells with large vacuoles (Fig. 4b), fewer starch grains, and
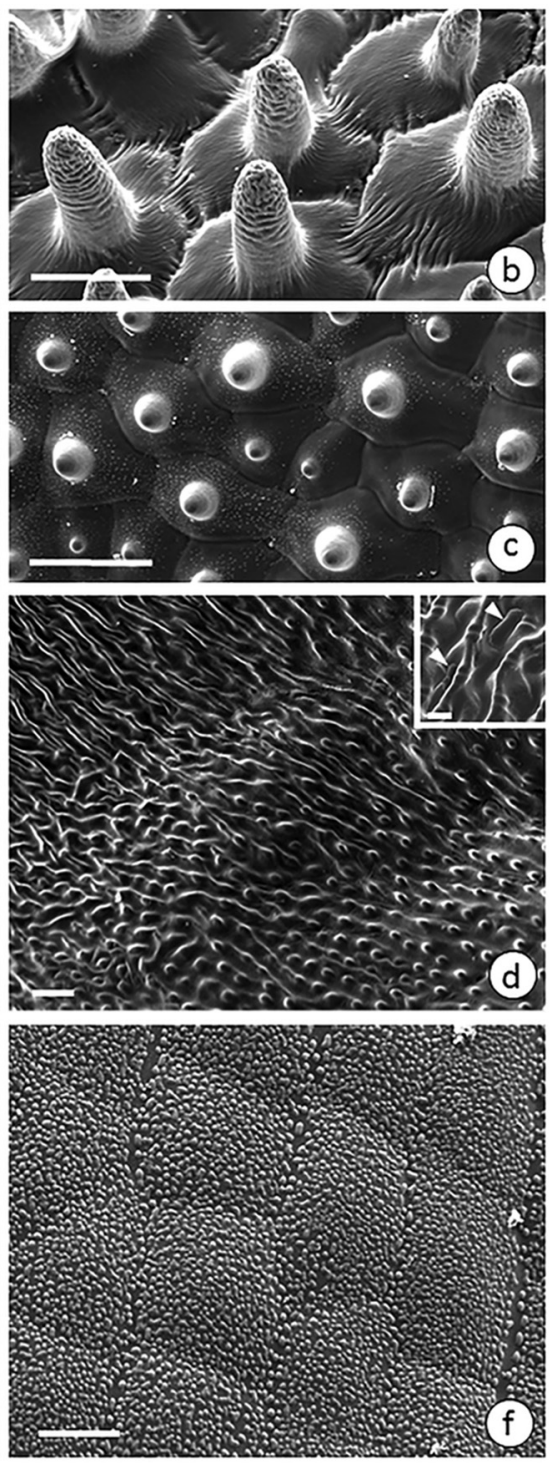

lower lipid contents. The epichile had rectangular epidermal cells covered with grains of epicuticular wax (Fig. 4g). Parenchyma cells had fewer starch grains when compared with the hypochile cells. In addition, reduced lipid and starch content was observed in the epichile parenchyma cells of first-day flowers.

By TEM, epidermal cells at different secretory stages were observed in the hypochile ventral region, which corresponds to the ridged surface. These cells exhibited a thicker outer periclinal wall with a lamellate structure (Fig. 5a). Some cells presented voluminous nuclei with a dense nucleolus, abundant cytoplasm rich in plastids filled with numerous small starch grains (Fig. 5a), and few osmiophilic granules (Fig. 5b). The plastids were concentrated in the basal pole of the cell and numerous 
Fig. 4. Light microscopy of G. bufonia floral lip. (a-f) Hypochile. (g) Epichile. (a) General aspect of the hypochile region. (b) Papillose epidermal cells on the dorsal surface of the hypochile region. $(c-f)$ Ventral surface of the hypochile. $(c)$ Epidermal cells with lipid material accumulations on the outer periclinal wall (thick arrows) stained with Sudan IV. (d) Epidermal cells with accumulations of terpene compounds, stained with Nadi reagent, on the cuticle surface (thick arrows). (e) Lipid droplets in parenchyma cells (arrowheads) stained with Sudan IV. (f) Starch grains in parenchyma cells contiguous to epidermis stained with Lugol. (g) Epichile epidermis with wax grains on the cuticle (arrows). Scale bars = $2 \mathrm{~mm}$ (Fig. $4 a$ ); $100 \mu \mathrm{m}$ (Fig. $4 b$ ); $50 \mu \mathrm{m}$ (Figs. $4 c-4 g$ ). (This figure is available in colour online.)
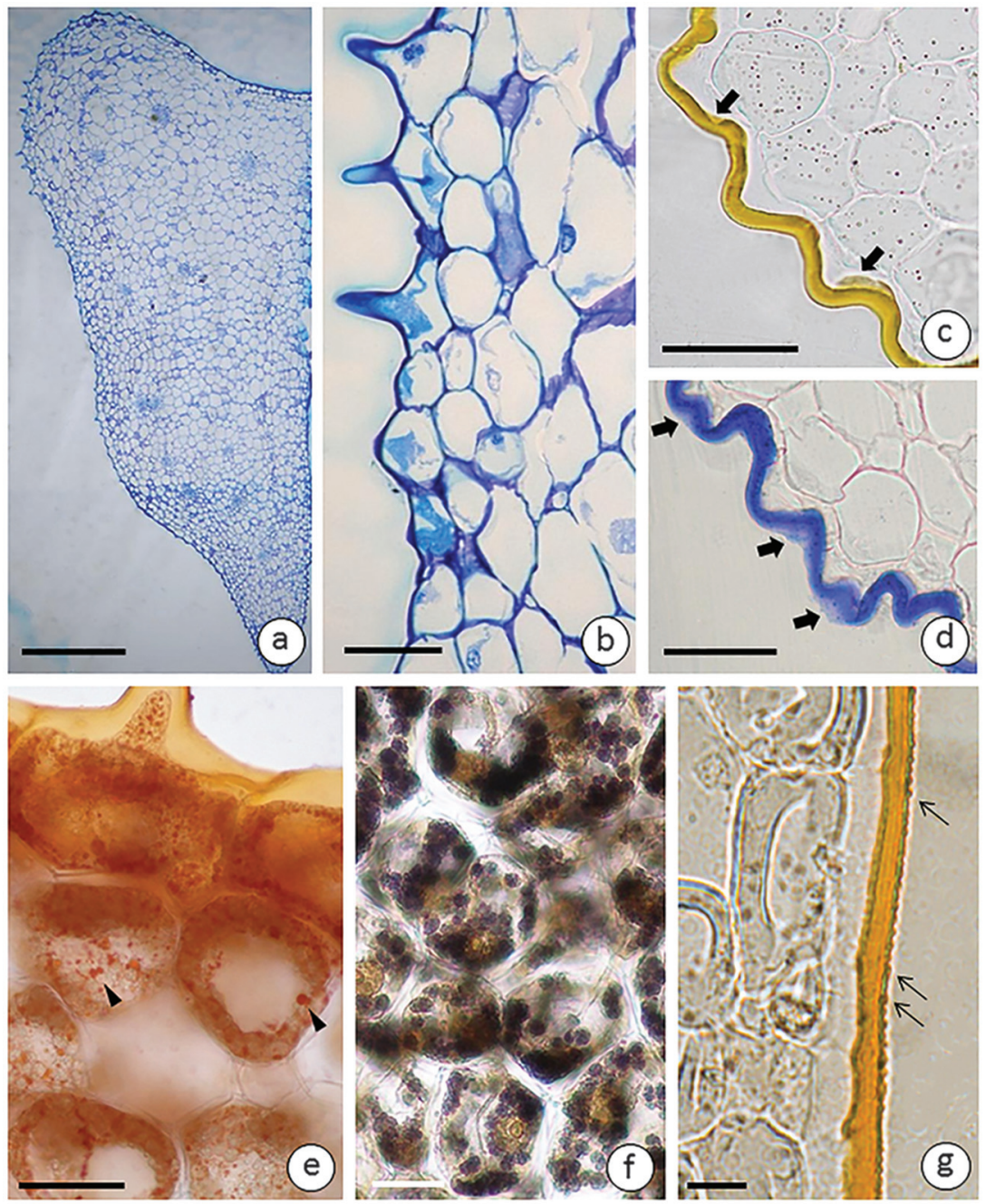

small vacuoles occurred at the distal pole (Fig. 5a). Ramified plasmodesmata traversed the walls between epidermal cells (Fig. 5b) and connected them with parenchyma cells (not shown). At this stage, images suggested that there was degradation of starch grains (Fig. 5b). Other epidermal cells were characterized by proliferated smooth endoplasmic reticulum (Fig. 5c), numerous mitochondria concentrated in the cell periphery along the anticlinal walls, and osmiophilic drops scattered into the cytoplasm and close to the plasma membrane (Fig. 5d). The plasma membrane was sinuous in outline with vesicles and (or) membranous structures occurring close to it (Figs. $5 d, 5 e$ ). Osmiophilic inclusions were observed in the periplasmic space (Fig. $5 d$ ). In some cells, two types of plastids were observed, one containing large osmiophilic inclusions and starch grains (Fig. 5e), and the other containing only osmiophilic inclusions (Fig. 5f). These epidermal cells were char- acterized by an abundance of larger osmiophilic inclusions, which were scattered in the cytoplasm, and by welldeveloped mitochondria (Fig. 5g). Epidermal cells that were apparently in the latter stage of secretion were characterized by the presence of one developed vacuole and a reduced cytoplasm that contained osmiophilic inclusions and abundant smooth endoplasmic reticulum (Fig. 5h). Osmiophilic material was also observed in cell wall lamellae and in the cuticle stratum that showed a well-developed net of microchannels (Fig. 5h).

In the epichile region of first-day flowers, the epidermal cells had accumulations of homogeneous material on the cuticle (Fig. 6a), which corresponded to the epicuticular wax that was observed under SEM (Figs. 4e, 4f). The outer periclinal cell wall was polylamellate and had porous external layers (Figs. 6a, 6b). This connected it with the cuticle stratum that was rich in randomly ar- 
Fig. 5. Transmission electron micrographs of the ventral surface of G. bufonia hypochile. (a) Epidermal cell with thick outer periclinal wall, voluminous nucleus, plastids with starch grains, and small vacuoles. (b) Ramified plasmodesmata traversing the walls between epidermal cells (arrows), starch grains (asterisks) and osmiophilic granules. (c) Proliferated smooth endoplasmic reticulum and plastid with starch grain (asterisk). (d) Mitochondria concentrated along anticlinal walls, osmiophilic drops in the cytoplasm, and osmiophilic inclusions in the periplasmic space (arrowheads). (e) Plastid containing osmiophilic inclusions and starch grains (asterisks). (f) Plastid containing only osmiophilic inclusions. (g) Osmiophilic inclusions scattered in the cytoplasm and mitochondria. (h) Epidermal cell in the latter stage of secretion with one developed vacuole, osmiophilic inclusions (arrowheads), and abundant smooth endoplasmic reticulum in the cytoplasm, the cell wall displays osmiophilic material inlaid among lamellae and in the cuticle stratum with a well-developed net of microchannels. Ct, cuticle; CW, cell wall; ER, endoplasmic reticulum; Mi, mitochondria; Nu, nucleus. Scale bars = $5 \mu \mathrm{m}$ (Fig. $5 a$ ); $2 \mu \mathrm{m}$ (Figs. 5b, 5c); $1 \mu \mathrm{m}$ (Fig. 5d); 500 nm (Figs. 5e-5h).
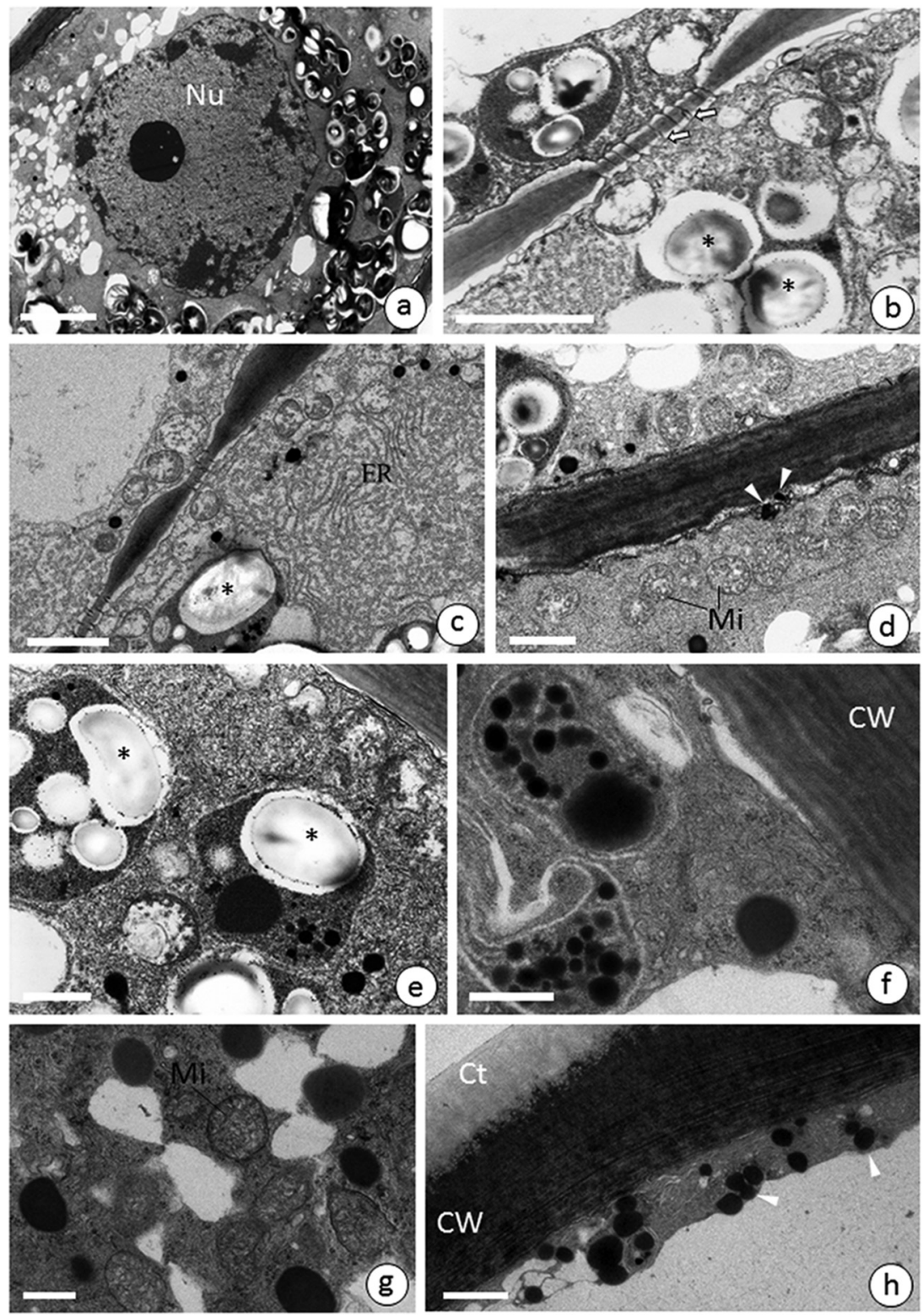

ranged microchannels (Fig. 6b). The cytoplasm was reduced to a thin peripheral layer and had well-developed mitochondria, an abundance of smooth endoplasmic reticulum, and osmiophilic drops that were scattered in the cytoplasm and in the periplasmic space (Fig. $6 c$ ). The plastids were ovoid in shape and contained globular starch grains and osmiophilic bodies of variable sizes and electron densities (Fig. 6d).

\section{Discussion}

Our data show that the floral lip of G. bufonia has three morphologically and functionally distinct regions, all related to the pollination mechanism: the hypochile, which is related to the fragrance secretion that seems to be the only primary attractive for Euglossini male bees; the epichile, which is associated with the wax deposits that seems to be related to the bee slip-and-fall episode; and 
Fig. 6. Transmission electron micrographs of G. bufonia epichile. (a) Wax deposits on the cuticle surface. (b) Polylamellate outer periclinal cell wall with porous external layers and microchannels (arrows) in the cuticular layer (c) Mitochondria, osmiophilic drops scattered in the cytoplasm and periplasmic space (arrowheads), and smooth endoplasmic reticulum. (d) Plastids with globular starch grains (asterisks) and osmiophilic bodies. Ct, cuticle; CW, cell wall; ER, endoplasmic reticulum. Scale bars $=1 \mu \mathrm{m}$ (Fig. 6a); $500 \mathrm{~nm}$ (Figs. 6b-6d).
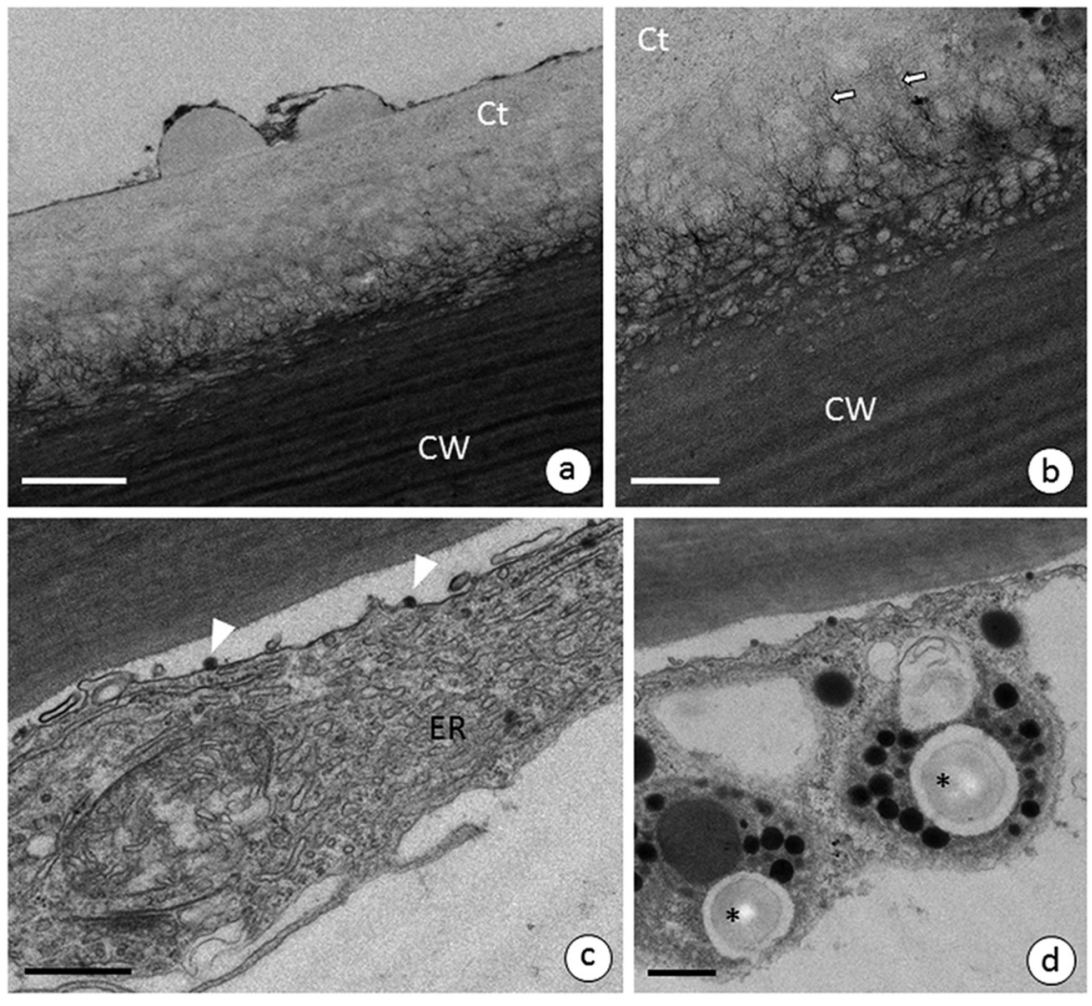

finally, the mesochile, the only nonsecretory region, which appears to assist in positioning the bee, and guides their fall on the column favouring the pollination.

Male Euglossini bees, Eufriesea violacea, were the only floral visitors observed on flowers of $G$. bufonia in the study area. The synchrony of flower opening creates an important visual display that attracts pollinators (Walsh et al. 2014), which could be responsible for the intense pollinator visits to G. bufonia flowers on the first day of anthesis. The scent gathering activity took place during the hottest hours of the day, probably as a result of increased scent emission, which overlapped with the most active period of the male E. violacea, following the pattern described for other species of Gongora and also for Stanhopea (Williams 1982). The behaviour of bees that included scraping the hypochile surface, hovering in front of the inflorescence, and making movements suggestive of a fragrance store in the chamber of hind tibia, indicates that the fragrance mediates this interaction. Additionally, E. violacea acted as effective pollinators of G. bufonia, and transferred the pollinia between flowers while they were gathering fragrance. This bee species was also observed visiting $G$. bufonia flowers in the coastal region of Brazil by Singer and Koehler (2003).

The fragrance produced by G. bufonia is mainly composed of benzaldehyde, p-cymene, linalool, myrcene, 2-phenylethyl acetate, and 2-phenylethyl alcohol (Williams and Whitten 1983). As reported by Vogel (1963) and Stern et al. (1986) in other species of orchids, in G. bufonia the osmophores were not highlighted by neutral red staining. This is probably due to the waxy cuticle that prevents the penetration of water-based stain. In this case, the starch presence, highlighted by iodine stain, may help in the osmophores location, as presumably, the starch serves as a substrate for fragrance production (Stern et al. 1987).

The osmophore region, as indicated by histochemical tests as Lugol, Nadi, and Sudan IV, was primarily composed of the ventral surface of the hypochile in G. bufonia, and this location is characteristic of orchids that are pollinated by male Euglossini bees (Antoń et al. 2012). However, the location of scent glands may vary in species that are pollinated by other functional groups and instead be located on the dorsal surface of the floral lip, e.g., in Cyclopogon elatus, which is pollinated by bees of Halictidae family (Wiemer et al. 2009), and in Cotylolabium lutzii, which has an unknown pollinator (Borba et al. 2014).

The osmophore of G. bufonia consisted of a secretory epidermis that was composed of papillose cells and secretory subepidermal parenchyma layers, as described by Ascensão et al. (2005) for Ophrys fusca and Ophrys lutea. The ultrastructure of these cells presented features that were associated with lipophilic secretion, as described 
for the osmophores of most orchids (Pridgeon and Stern 1983, 1985; Stern et al. 1987; Curry et al. 1991; Stpiczyńska 1993, 2001; Ascensão et al. 2005; Antoń et al. 2012; Kowalkowska et al. 2015).

We hypothesize that different cell types in the epidermis, such as the gradient that occurs from the coneshaped papillae to ridge-like cells of the hypochile may be responsible, when combined with flower pigmentation, for small temperature differences on the floral lip surface as discussed by Whitney et al. (2011). These small differences in temperature, which are generated by the conical shape of the epidermal cells, and flowers with darker colours, can influence the emission of volatile substances under distinct conditions (Whitney et al. 2011). This factor is associated with regions of the sepals and lip that have contrasting colours in G. bufonia and can influence the release of fragrance and consequently pollinator behaviour, as described for several species of the genus Ophrys (Bradshaw et al. 2010). The authors suggested that this influence could be visually detected by the visiting insect, or indirectly detected by the differential release of pseudopheromones by osmophores located in different coloured areas of the floral lip.

The large numbers of starch grains in the epidermal and subepidermal cells of osmophore in G. bufonia floral lip may represent an important source of carbon energy that is used for the biosynthesis of fragrances, as described for other orchid species (Stern et al 1987). The increasing number of vacuoles observed in this study is typical after scent production and secretion, and this process is accompanied by degradation of starch grains as reported by Stern et al. (1987). The increased number of large vacuoles observed in cells farthest from the epidermis is very similar to that found in Stanhopea oculata and Stanhopea wardii, where presumably these cells participate less actively in the secretory process than the epidermal or immediately subtending cells (Stern et al. 1987). The presence of osmiophilic droplets inside plastids and in the periplasmic space of epidermal and subepidermal cells of G. bufonia osmophore, suggests that both cell types are involved in the secretory process. Our results suggest that the fragrance accumulated in the depressions between the osmophores' ridges of $G$. bufonia is transported to the hypochile surface, from the periplasmic space, through microchannels that are formed by the reticulated cuticle as described for Anacamptis pyramidalis f. fumeauxiana, and Bulbophyllum wendlandianum (Kowalkowska et al. 2012, 2015).

The epichile surface of $G$. bufonia was covered by epicuticular wax grains, which can aid in pollination by generating instability in the positioning and fixing of the pollinator to the flower lip, and causing it to fall. A similar mechanism occurs in modified leaves of the insectivorous plant Nepenthes alata, which also present epicuticular waxes. However, in that case, the wax is involved in trapping insects that serve as essential nutritional supplement for this type of plant (Riedel et al. 2003). This slip-and- fall mechanism of the G. bufonia pollinator is compatible with the flower morphology, in which the column is lower and in an antagonistic position to the lip, thus promoting the acquisition of the pollinarium or the deposition of pollinia on the stigma whilst the bees are slipping through the column.

The approach taken in our study, bringing together knowledge of the pollination ecology and detailed floral lip morphology, allowed for a more complete understanding of the mechanism involved in the slip-and-fall pollination of $G$. bufonia. We verified that this is dependent on integration between the floral lip secretory features and the morphology and behaviour of pollinator bees.

\section{Conflicts of interest}

The authors declare no conflict of interest in relation to this publication.

\section{Acknowledgements}

We thank S. Mateus for the identification of Eufriesea violacea; Fundação de Amparo à Pesquisa do Estado de São Paulo (Proc. 2008/55434-7) and Conselho Nacional de Desenvolvimento Científico e Tecnológico (Proc. 301464/ 2008) for the grant to S.R. Machado; the staff of Centro de Microscopia Eletrônica - IBB, UNESP for lab assistance; and two anonymous reviewers for their helpful comments on the manuscript.

\section{References}

Allen, P.H. 1954. Pollination in Gongora maculata. Ceiba, 4: 121125.

Antoń, S., Kamińska, M., and Stpiczyńska, M. 2012. Comparative structure of the osmophores in the flower of Stanhopea graveolens L. and Cycnoches chlorochilon Klotzsch (Orchidaceae). Acta Agrobot. 65: 11-22. doi:10.5586/aa.2012.054.

Ascensão, L., Francisco, A., Cotrim, H., and Pais, M.S. 2005. Comparative structure of the labellum in Ophrys fusca and O. lutea (Orchidaceae). Am. J. Bot. 92(7):1059-1067. doi:10.3732/ajb.92. 7.1059. PMID:21646127.

Bembé, B. 2004. Functional morphology in male euglossine bees and their ability to spray fragrances (Hymenoptera, Apidae, Euglossini). Apidologie, 35(3): 283-291. doi:10.1051/ apido:2004013.

Borba, E.L., Salazar, G.A., Mazzoni-Viveiros, S., and Batista, J.A.N. 2014. Phylogenetic position and floral morphology of the Brazilian endemic, monospecific genus Cotylolabium: a sister group for the remaining Spiranthinae (Orchidaceae). Bot. J. Linn. Soc. 175(1): 29-46. doi:10.1111/boj.12136.

Bradshaw, E., Rudall, P.J., Devey, D.S., Thomas, M.M., Glover, B.J., and Bateman, R.M. 2010. Comparative labellum micromorphology in the sexually deceptive temperate orchid genus Ophrys: diverse epidermal cell types and multiple origins of structural colour. Bot. J. Linn. Soc. 162(3): 502-540. doi:10.1111/j.1095-8339.2010.01033.x.

Cruz-Landim, C., Stort, A.C., Cruz, M.A.C., and Kitajima, E.W. 1965 Orgão tibial dos machos de Euglossini. Estudo ao microscópio Óptico e electrônico. Rev. Bras. Biol. 25: 323-341.

Curry, K.J., McDowell, L.M., Judd, W.S., and Stern, W.L. 1991. Osmophores, floral features, and systematics of Stanhopea (Orchidaceae). Am. J. Bot. 78(5): 610-623. doi:10.2307/2445082.

Dafni, A., Kevan, P.G., and Husband, B.C. (Editors). 2005. Practical pollination biology. Enviroquest Ltd., Cambridge, Ont.

David, R., and Carde, J.P. 1964. Coloration différentielle des inclu- 
sions lipidique et terpeniques des pseudophylles du Pin maritime au moyen du reactif Nadi. C.R. Acad. Sci. Paris, 257: 1338-1340.

Dressler, R.L. 1968. Pollination by euglossine bees. Evolution, 22(1): 202-210. doi:10.2307/2406664.

Dressler, R.L. 1982. Biology of the orchid bees (Euglossini). Annu. Rev. Ecol. Syst. 13: 373-394. doi:10.1146/annurev.es.13. 110182.002105.

Dressler, R.L. 1993. Phylogeny and classification of the orchid family. Dioscorides Press, Portland, Ore.

Eltz, T., Whitten, W.M., Roubik, D.W., and Linsenmair, K.E. 1999. Fragrance collection, storage, and accumulation by individual male orchid bees. J. Chem. Ecol. 25(1): 157-176. doi: 10.1023/A:1020897302355.

Eltz, T., Sager, A., and Lunau, K. 2005. Juggling with volatiles: exposure of perfumes by displaying male orchid bees. J. Comp. Physiol. A, 191(7): 575-581. doi:10.1007/s00359-005-0603-2.

Hoehne, F.C. 1942. Flora Brasilica. Secretaria da Agricultura, Indústria e Comércio de São Paulo, São Paulo, Brasil.

Jensen, W.A. 1962. Botanical histochemistry. W.H. Freeman and Co., San Francisco, Calif.

Johansen, D.A. 1940. Plant microtechnique. Mc Graw Hill, New York.

Kowalkowska, A.K., Margońska, H.B., KozieradzkaKiszkurno, M., and Bohdanowicz, J. 2012. Studies on the ultrastructure of a three-spurred fumeauxiana form of Anacamptis pyramidalis. Plant. Syst. Evol. 298(6): 1025-1035. doi:10.1007/s00606012-0611-y.

Kowalkowska, A.K., Kozieradzka-Kiszkurno, M., and Turzyński, S. 2015. Morphological, histological and ultrastructural features of osmophores and nectary of Bulbophyllum wendlandianum (Kraenzl.) Dammer (B. section Cirrhopetalum Lindl., Bulbophyllinae Schltr., Orchidaceae). Plant. Syst. Evol. 301(2): 609622. doi:10.1007/s00606-014-1100-2.

Martini, P., Schlindwein, C., and Montenegro, A. 2003. Pollination, flower longevity, and reproductive biology of Gongora quinquenervis Ruíz and Pavón (Orchidaceae) in an Atlantic forest fragment of Pernambuco, Brazil. Plant Biol. 5(5): 495-503. doi:10.1055/s-2003-44785.

Mazia, D., Brewer, P.A., and Alfert, M. 1953. The cytochemical staining and measurement of protein with mercuric bromophenol blue. Biol. Bull. 104: 57-67. doi:10.2307/1538691.

O’Brien, T.P., Feder, N., and McCully, M.E. 1964. Polychromatic staining of plant cell walls by toluidine blue O. Protoplasma, 59(2): 368-373. doi:10.1007/BF01248568.

Pansarin, E.R., and Amaral, M.C.E. 2009. Reproductive biology and pollination of southeastern Brazilian Stanhopea Frost ex Hook. (Orchidaceae). Flora, 204(3):238-249. doi:10.1016/j.flora. 2008.01.014.

Pansarin, L.M., Castro, M., and Sazima, M. 2009. Osmophore and elaiophores of Grobya amherstiae (Catasetinae, Orchidaceae) and their relation to pollination. Bot. J. Linn. Soc. 159(3): 408-415. doi:10.1111/j.1095-8339.2009.00953.x.

Pridgeon, A.M., and Stern, W.L. 1983. Ultrastructure of osmophores in Restrepia (Orchidaceae). Am. J. Bot. 70(8): 1233-1243. doi: $10.2307 / 2443293$.

Pridgeon, A.M., and Stern, W.L. 1985. Osmophores of Scaphosepalum (Orchidaceae). Bot. Gaz. 146(1):115-123. doi:10.1086/337505.

Reynolds, E.S. 1963. The use of lead citrate at high $\mathrm{pH}$ as an electron-opaque stain in electron microscopy. J. Cell Biol. 17: 208-212. doi:10.1083/jcb.17.1.208. PMID:13986422.

Riedel, M., Eichner, A., and Jetter, R. 2003. Slippery surfaces of carnivorous plants: composition of epicuticular wax crystals in Nepenthes alata Blanco pitchers. Planta, 218(1): 87-97. doi: 10.1007/s00425-003-1075-7. PMID:12883887.

Romanini, R.P., and Barros, F. 2007. Flora fanerogâmica da Ilha do Cardoso (São Paulo, Brasil): Orchidaceae. In Flora faner- ogâmica da Ilha do Cardoso. Edited by M.M.R.F. Melo, F. Barros, S.A.C. Chiea, M. Kirizawa, S.L. Jung-Mendaçolli, and M.G.L. Wanderley. Instituto de Botânica, São Paulo. No. 12. pp. 29-275.

Sass, J.E. 1951. Botanical microtechnique. Iowa State College Press, Iowa.

Singer, R.B., and Koehler, S. 2003. Notes on the pollination of Notylia nemorosa (Orchidaceae: Oncidiinae): do pollinators necessarily promote cross-pollination? J. Plant Res. 116(1): 19-25. doi:10.1007/s00442-005-0165-6. PMID:12605296.

Stern, W.L., Curry, K.J., and Whitten, W.M. 1986. Staining fragrance glands in orchid flowers. Bull. Torrey Bot. Club, 113(3): 288-297. doi:10.2307/2996368.

Stern, W.L., Curry, K.J., and Pridgeon, A.M. 1987. Osmophores of Stanhopea (Orchidaceae). Am. J. Bot. 74(9): 1323-1331. doi:10. 2307/2444310.

Stpiczyńska, M. 1993. Anatomy and ultrastructure of osmophores of Cymbidium tracyanum Rolfe (Orchidaceae). Acta Soc. Bot. Pol. 62(1-2): 5-9. doi:10.5586/asbp.1993.001.

Stpiczyńska, M. 2001. Osmophores of the fragrant orchid Gymnadenia conopsea L. (Orchidaceae). Acta Soc. Bot. Pol. 70(2): 91-96. doi:10.5586/asbp.2001.012.

Svendsen, A.B., and Verpoorte, R. 1983. Chromatography of alkaloids. Elsevier Scientific Publishing Company, New York.

Van der Pijl, L., and Dodson, C.H. 1966. Orchid flowers: their pollination and evolution. University of Miami Press, Coral Gables, Fla.

Vogel, S. 1963. Duftdrüsen im Dienste der Bestäubung. über Bau und Funktion der Osmophoren. Akademie der Wissenschaften und der Literatur. Mainz, 10: 1-165.

Vogel, S. 1990. The role of scent glands in pollination: on the structure and function of osmophores. Amerind Publishing, New Delhi, India.

Walsh, R.P., Arnold, P.M., and Michaels, H.J. 2014. Effects of pollination limitation and seed predation on female reproductive success of a deceptive orchid. AoB PLANTS, 6: plu031. doi:10.1093/aobpla/plu031. PMID:24916060.

Whitney, H.M., Bennett, K.M.V., Dorling, M., Sandbach, L., Prince, D., Chittka, L., and Glover, B.J. 2011. Why do so many petals have conical epidermal cells? Ann. Bot. 108(4): 609616. doi:10.1093/aob/mcr065. PMID:21470973.

Whitten, W.M., Young, A.M., and Williams, N.H. 1989. Function of glandular secretions in fragrance collection by male euglossine bees (Apidae: Euglossini). J. Chem. Ecol. 15(4): 12851295. doi:10.1007/BF01014830. PMID:24272012.

Whitten, W.M., Young, A.M., and Stern, D.L. 1993. Nonfloral sources of chemicals that attract male euglossine bees (Apidae: Euglossini). J. Chem. Ecol. 19(12): 3017-3027. doi:10.1007| BF00980599. PMID:24248792.

Wiemer, A.P., Moré, M., Benitez-Vieyra, S., Cocucci, A.A., Raguso, R.A., and Sérsic, A.N. 2009. A simple floral fragrance and unusual osmophore structure in Cyclopogon elatus (Orchidaceae). Plant Biol.11(4):506-514. doi:10.1111/j.1438-8677.2008. 00140.x. PMID:19538389.

Williams, N.H. 1982. The biology of orchids and euglossine bees. In Orchid biology: reviews and perspectives. Edited by J. Arditti. Ithaca, Cornell University Press, New York. pp. 119-171.

Williams, N.H., and Whitten, W.M. 1983. Orchid floral fragrances and male euglossine bees: methods and advances in the last sesquidecade. Biol. Bull. 164(3): 355-395. doi:10.2307| 1541248.

Willmer, P. 2011. Pollination and floral ecology. University Press, Princeton.

Zimmermann, Y., Roubik, D.W., and Eltz, T. 2006. Speciesspecific attraction to pheromonal analogues in orchid bees. Behav. Ecol. Sociobiol. 60: 833-843. doi:10.1007/s00265-0060227-8. 
Copyright of Botany is the property of Canadian Science Publishing and its content may not be copied or emailed to multiple sites or posted to a listserv without the copyright holder's express written permission. However, users may print, download, or email articles for individual use. 